\title{
5
}

\section{SPAIN: INNOVATION AND DIVERSIFICATION IN TIMES OF PANDEMIC}

DOI: https://doi.org/10.7764/obitel.21.E.7

\begin{abstract}
Authors:
Charo Lacalle (https://orcid.org/0000-0002-0024-6591), Beatriz Gómez (http://orcid.org/0000-0002-0557-528X),

Mariluz Sánchez (https://orcid.org/0000-0002-0076-7522), Javier Mateos-Pérez (https://orcid.org/0000-0003-2056-8704)

\section{Team:}

Sara Narvaiza, Rosa Ferrer, Raquel Crisóstomo, Tatiana Hidalgo-Marí, Berta Trullàs, Daria Dergacheva, Jesús Segarra-Saavedra
\end{abstract}

\section{Introduction}

The State of Emergency and the Stay-at-Home order in Spain due to the pandemic, have determined the spectacular increase in television consumption in 2020, which has also resulted in a notable increase of VOD subscribers. Despite the shutdown of production processes during the first wave and the subsequent rise in costs due to the effect of the anti-COVID-19 measures, Spanish fiction confirms its dynamism in the high number of titles offered throughout the year. The tendency of the two large private channels to program their premieres on VOD is undoubtedly one of the outstanding aspects. 


\section{The audiovisual context of Spain in 2020}

The annual weighted audience index of the three largest generalist channels reaches a new all-time low $(35.8 \%,-0.1)$. Pay TV, on the other hand, achieves a new record $(8.4 \%,+0.4)$, surpassing the regional networks $(8.2 \%)$, which maintain their 2019 results. The exceptional situation increases consumption television, while advertising investment experienced a high decline.

\subsection{Open television in Spain}

The main public and private television networks suffer as a result of the increase in pay TV offers. Despite some significant increases, such as that of Nova $(+0.3)$, Trece $(+0.2)$, or BeMadTV $(+0.2)$, the accumulated index of the specialty channels (DTT) also weakens $(28.7 \%,-0.4)$ as a consequence of the results of FDF, Neox and the children's networks (Clan, Boing, and Disney Channel), which reached their lowest in the last 10 years.

\section{Chart 1. Open TV networks in Spain}

\begin{tabular}{|c|c|c|c|c|}
\hline Reach & \multicolumn{2}{|c|}{ Public } & \multicolumn{2}{|r|}{ Private } \\
\hline \multirow{2}{*}{$\begin{array}{l}\text { State (national } \\
\text { coverage) } 1\end{array}$} & First channel & Second channel & $\begin{array}{l}\text { First } \\
\text { channel }\end{array}$ & Second Channel \\
\hline & Lal & $\begin{array}{l}\text { La2 } \\
24 \mathrm{H} \\
\text { Clan } \\
\text { Teledeporte }\end{array}$ & $\begin{array}{l}\text { Antena3, } \\
\text { Cuatro, } \\
\text { LaSexta, } \\
\text { Tele5 }\end{array}$ & $\begin{array}{l}\text { Atreseries, BEMADtv, Boing, } \\
\text { Disney Channel, Divinity, DKISS, } \\
\text { DMax, El Toro TV, Energy, FDF, } \\
\text { Gol, Mega, Neox, Nova, } \\
\text { Paramount Network, Real Madrid } \\
\text { HD, Ten, Trece }\end{array}$ \\
\hline $\begin{array}{l}\text { Autonomic } \\
\text { (regional } \\
\text { coverage) }\end{array}$ & $\begin{array}{l}\text { Á punt, Aragón } \\
\text { TV, CanalSur, } \\
\text { CMM, ETB1, } \\
\text { ETB2, C. } \\
\text { Extremadura, } \\
\text { IB3, Telemadrid, } \\
\text { TPA, TV3, } \\
\text { TVCAN, TVG }\end{array}$ & $\begin{array}{l}\text { 3/24, And-TV, } \\
\text { CSur-And, } \\
\text { Esport3, ETB3, } \\
\text { ETB4, Galicia TV, } \\
\text { LaOtra, Super3/33, } \\
\text { TPA2, TV3CAT, } \\
\text { TVG2 }\end{array}$ & \multicolumn{2}{|c|}{$\begin{array}{l}\text { 8Madrid, 8TV, BOM Cine, HitTV, La7, La8 } \\
\text { Mediterráneo, Fibracat TV }\end{array}$} \\
\hline
\end{tabular}

Source: Obitel España

1 In the Spanish case, "state coverage" or "national coverage" refer to networks that reach the whole country, while "automatic coverage" refers to networks with regional coverage of their own Automatic Communities. Both 
After the declaration of the State of Emergency on March 14, practically all of Spanish society was forced to stay at home to stop the spread of the coronavirus. The confinement of the population had an immediate impact on television consumption (live and recorded), which reversed its negative trend of the last two years and added 18 minutes in relation to 2019, with 240 minutes per person per day in 2020 (a figure identical to 2017). However, it should be noted that this year there have been two important changes in the measurement of audiences, with the introduction of second homes in January and the expansion of the number of people meters (5,720 households in October).

For the ninth consecutive year, Tele5 has been the most watched network $(14.6 \%,-0.2)$, followed by Antena3 $(11.8 \%,+0.1)$ and La1, which repeats its annual historical low with the same index as last year's (9.4\%). LaSexta also offers a result identical to that of 2019 (7\%), while Cuatro stands at 5.4\% $(+0.1)$.

\section{Graph 1. Share by state networks}

\begin{tabular}{|l|c|}
\hline \multicolumn{1}{|c|}{ Channel } & Share (\%) \\
\hline Tele5 & 14.6 \\
\hline A3 & 11.8 \\
\hline La1 & 9.4 \\
\hline TDT pago & 8.4 \\
\hline Autonómicas & 8.2 \\
\hline LaSexta & 7 \\
\hline Cuatro & 5.4 \\
\hline La 2 & 2.8 \\
\hline TDT abierto & 28.7 \\
\hline Otras & 3.7 \\
\hline TOTAL & $\mathbf{1 0 0}$ \\
\hline
\end{tabular}




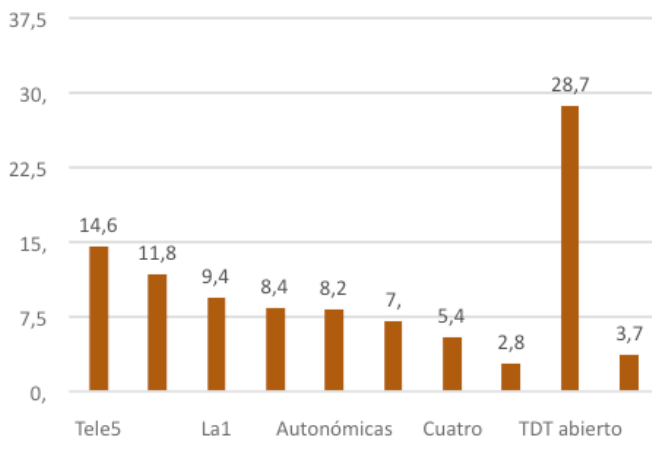

Source: Barlovento Comunicación/KantarMedia.

The public autonomic channels $(8.2 \%)$, as well as the private ones $(0.4 \%)$, keep the same records from 2019; that is, the best result since 2014 for the former and the annual minimum of the decade for the latter. TV3 $(14.6 \%)$ is, once again, the network with the highest audience share of the whole and confirms its leadership in Catalonia for the eleventh consecutive year. It is followed by ETB2 $(10 \%,+1.7)$, thus displacing TVG $(9.9 \%,+0.6)$ to third place.

Graph 1a. Share by autonomic networks

\begin{tabular}{|l|c|l|c|}
\hline \multicolumn{1}{|c|}{ Channel } & $\%$ & \multicolumn{1}{|c|}{ Channel } & $\%$ \\
\hline TV3 & 14.6 & Telemadrid & 5.4 \\
\hline ETB2 & 10 & IB3 & 4.7 \\
\hline TVG & 9.9 & LA 7TV & 4 \\
\hline AragónTV & 9.3 & À punt & 3 \\
\hline C. Sur & 7.5 & ETB1 & 1.7 \\
\hline TPA & 6.8 & $3 / / 24$ & 1.7 \\
\hline C. Extremadura & 6.2 & TPA2 & 1.1 \\
\hline TV CAN & 5.9 & La Otra & 0.9 \\
\hline CMM & 5.6 & TVG2 & 0.7 \\
\hline Super3/33 & 0.6 & ETB3 & 0.3 \\
\hline ETB4 & 0.6 & Csur_And & 0.2 \\
\hline TV3CAT & 0.4 & Galicia TV & 0.1 \\
\hline And. TV & 0.4 & Privadas & 0.4 \\
\hline Esport3 & 0.3 & - & $\mathbf{1 0 0}$ \\
\hline TOTAL & & &
\end{tabular}




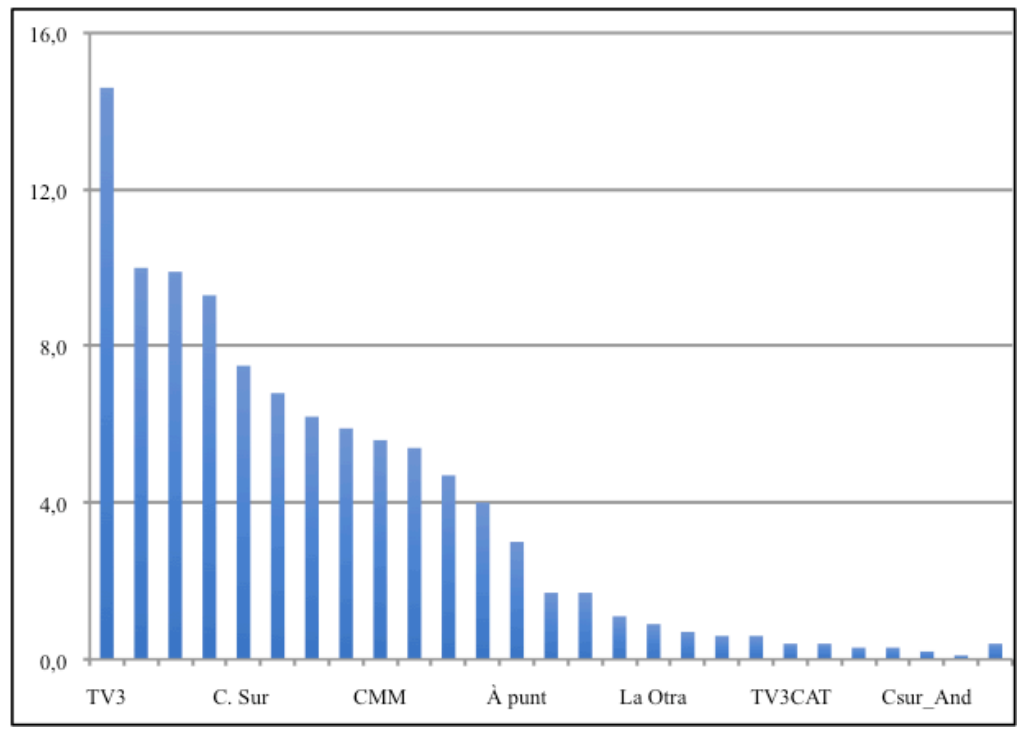

Source: Barlovento Comunicación/KantarMedia.

Leadership by business groups corresponds, once again, to Mediaset $(28.4 \%,-0.5)$, followed by Atresmedia $(26.3 \%,+0.1)$. Thus, the audience share of both leaders represents more than half of the total (54.8\%), although they once again lose four tenths compared to 2019. RTVE gets $15.4 \%$ (-0.1 points); while FORTA (8.1\%) repeats the result. Both Vocento (2.6\%) and Unidad Editorial (2.5\%) lost three tenths.

Fiction is down compared to 2019 , but it is still the genre with the highest presence in the networks $(42.3 \%,-0.4)$, followed by entertainment $(17.8 \%,+0.6)$, culture $(13.7 \%,+0.3)$, sports $(10.8 \%,-0.8)$ and information $(9.8 \%,+0.7)$. Despite its leadership among genres, no fiction show is in the top 50 most viewed broadcasts of the year. 
Graph 2. Offer by genre in TV programming

\begin{tabular}{|l|c|}
\hline \multicolumn{1}{|c|}{ Genre } & \% \\
\hline Fiction & 42.3 \\
\hline Entertainment & 17.8 \\
\hline Culture & 13.7 \\
\hline Sports & 10.8 \\
\hline Information & 9.8 \\
\hline Music & 2.7 \\
\hline Contests & 2.1 \\
\hline Others & 0.3 \\
\hline Religious & 0.2 \\
\hline TOTAL & $\mathbf{1 0 0}$ \\
\hline
\end{tabular}

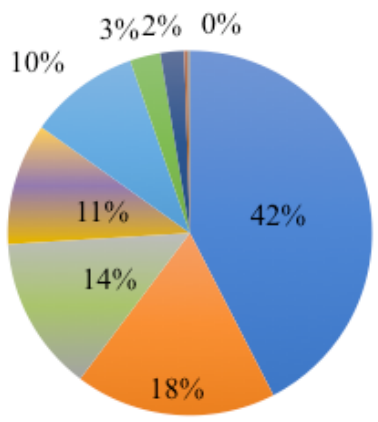

- Ficción

Entretenimiento

Cultura

= Deporte

Información

- Música

- Concursos

Otros

- Religiosos

Source: Barlovento Comunicación/KantarMedia.

In economic terms, 2020 has not been a good year for the three main audiovisual groups. RTVE closed the year with losses of 
around 50 million euros, that is, almost double those of 2019 (29.67 million euros), although slightly lower than the estimates for July (60 million) $)^{2}$. In 2020, Mediaset obtained 178.7 million benefits, $15.6 \%$ less than in 20193; and Atresmedia earned 23.8 million, which implies a decrease of $79.8 \%$ compared to the previous year ${ }^{4}$. The budget that suffered the most in both groups was advertising (see section 1.4).

\subsection{Pay TV and VOD in Spain}

DTT (74\%) maintains its 2019 record and continues to be the main television content distribution system in Spain. However, it once again leads with its all-time low as a result of the increase in pay television subscriptions (IPTV cable or satellite), which, on the contrary, marks a new record $(26.4 \%,+0.7)$ thanks to the increase in the IPTV system $(16 \%+1.5)$.

In September 2020, 7,967,202 households were subscribed to some form of pay television ${ }^{5}, 15.5 \%$ more than last year. In the first nine months of the year, pay television revenues amounted to $1,582.65$ million euros $(-5.4 \%)$, while those of open-access television represented 938.36 million $(-22 \%){ }^{6}$

Specialty pay channels average $8.4 \%$ audience (see Graph 1 ), four tenths more than in 2019, which marks a new historical record. Among the ten most viewed pay networks are Fox Spain, responsible for the continuation of Vis a Vis (Vis a Vis. El Oasis); TNT, which premiered Vamos Juan in 2020, and \# 0, which broadcasts the vast range of original fiction from Movistar + .

2 https://vertele.eldiario.es/noticias/RTVE-presupuesto-2021-1127-millones-subidaRosa-Maria-Mateo 0 2283971628.html

3 https://files.mediaset.es/file/10002/2021/02/24/FY_20_SPANISH_CNMV_f7a7.pdf

4 https://www.atresmediacorporacion.com/documents/2021/02/25/ACCF96 $\overline{\mathrm{A}} 3-2088$ 4208-8394-DD4B4DCEB6D7/atresmediaresultados_2020cnmv.pdf

5 http://data.cnmc.es/datagraph/jsp/inf_trim.jsp

$6 \mathrm{http} / / /$ data.cnmc.es/datagraph/jsp/inf_trim.jsp 


\section{Chart 2. Pay TV Channel in Spain}

\begin{tabular}{|l|}
\hline \multicolumn{1}{|c|}{$\begin{array}{c}\text { Top } 10 \text { Most Watched Pay TV } \\
\text { Networks in } 2020\end{array}$} \\
\hline 1) Movistar Laliga (soccer), 2) Fox \\
(fiction), 3) AXN (fiction), 4) TNT \\
(fiction), 5) Calle 13 (fiction), \\
6) Canal Hollywood (movies), \\
7) Comedy Central (comedy), \\
8) Fox Life (entertainment), 9) \#0 \\
(entertainment), 10) Historia \\
(documentaries) \\
\hline TOTAL: 10 news channels \\
\hline
\end{tabular}

Source: Barlovento Comunicación/KantarMedia

\section{Chart 3. VOD in Spain}

\begin{tabular}{|c|c|}
\hline Main active VOD platforms in 2020 & Total \\
\hline $\begin{array}{l}\text { Netflix, Amazon Prime Video, HBO, } \\
\text { Disney+, Apple TV, Movistar+ y } \\
\text { Movistar+ Lite (Telefónica), Vodafone } \\
\text { TV (Vodafone), Orange TV (Orange), } \\
\text { Starzplay, Rakuten TV, Pluto TV, } \\
\text { fuboTV, Sky, Filmin, Cineclick, } \\
\text { FlixOlé, DAZN, Acorn TV, LovesTV, } \\
\text { RTVEalacarta.es (TVE), Atresplayer } \\
\text { Premium (Atresmedia), Mitele Plus } \\
\text { (Mediaset), Mubi, IQiyi, Crunchyroll, } \\
\text { Quibi, Planet Horror }\end{array}$ & 28 \\
\hline TOTAL & 28 \\
\hline
\end{tabular}

Source: Obitel España 


\subsection{Independent producers of TV fiction}

For a couple of years, the profound changes in the Spanish audiovisual scene have been turning competitors into business partners. Among other 2020 alliances, Atresmedia and Telefónica joined forces in June to create Buendía Estudios, with the aim of producing internationally. Warner Bros. and Alea Media, Aitor Gabilondo's production company, also signed an agreement to develop two television series, while the strategic alliances between Mediapro and Orange on the one hand, and Mediapro with Hulu Japan and HBO Asia on the other, bore their first fruits with the series Caminantes, in the first case, and The Head in the latter.

\subsection{Sources of financing for the audiovisual sector}

Investment in advertising has continued its negative trend and, for the second year in a row, television has ceased to be the leader among the media, a position now occupied by the Digital category. Advertising investment in television decreased by $18.4 \%$ compared to the previous year, with a total of 1,640.3 million euros. Advertising investment of national open over-the-air networks fell by $19.2 \%(1,459.2$ million euros), placing its market share at $89 \%(-0.9)$; while among autonomic televisions the decrease represented $12.6 \%$ (79.3 million euros), with a share of $4.8 \%(+0.3)$. Payment channels showed a decrease of $8.9 \%$ (99.7 million), with a market share of $6.1 \%(+0.7)^{7}$. In April, the government approved 15 million in aid for private television channels in order to alleviate the drastic drop in advertising investment. 
According to Infoadex data, Mediaset's advertising revenue registered 709 million euros, $18.4 \%$ less than the previous year; while Atresmedia registered 656.1 million, a decrease of $19.5 \%$ compared to 2019. With these results, Mediaset obtained a market share of $43.2 \%$ and Atresmedia, 40\%, which means that the two leaders of broadcast television in Spain maintained their hegemony in advertising revenues: $83.2 \%$ of total investment in television. ${ }^{8}$

\subsection{Communication Policies}

In November 2020, the Executive Government presented the draft of the new General Audiovisual Communication Law, better known as the "Netflix rate", which forces "providers of television audiovisual communication service on demand", that is, new platforms of video and the rest of new operators, to allocate $5 \%$ of the income generated in Spain to finance European audiovisual work or to contribute to the ICAA Film Protection Fund. However, and contrary to expectations, this new legislation does not cover the financing of RTVE, to which private television channels and telecommunications operators contribute instead. It is, therefore, a comparative offense for the rest of the operators, which the Union of Open-Access Commercial Televisions (UTECA) has already denounced.

\subsection{Digital and mobile connectivity infrastructure}

In June, Spain informed the European Union that, as a result of the exceptional situation generated by COVID-19, it was impossible to complete the Second Digital Dividend before the 30th of the same

8 https://www.infoadex.es/home/wp-content/uploads/2021/02/NP-Estudio-InfoAdex-dela-Inversión-Publicitaria-en-España-2021.pdf 
month; that is, the process by which the frequencies of the $700 \mathrm{MHz}$ band, now occupied by DTT channels, are released to be used for the deployment of $5 \mathrm{G}$ networks. Thus, October 31 was set as the new date for completion. In order to pay for the necessary changes in the transmitting equipment, the Council of Ministers approved in July subsidies for a maximum amount of 10 million euros to private televisions. That same month, RTVE launched the restored 4K versions of Don Quijote and La Regenta, the first two works of the corporation's Documentary Fund that have been remastered in ultra-high definition.

\section{Analysis of the year}

The number of premieres of domestic fiction in 2020 amounts to 75 titles (13 state, 18 regional, and 43 VOD), one more than last year. This is truly remarkable in times of pandemic, mainly due to the extraordinary contribution of payment platforms, which confirms the dynamism of Spanish fiction. VOD's momentum has introduced radical changes in the programming strategies of the two largest private state networks, which have chosen to premiere some of their fictions in streaming.

Antena3 open-access offer only includes two serials: El Secreto del Puente Viejo and Amar Es para Siempre, while the rest of its fictions were transferred to Atresplayer, a trend that started last year with a thriller currently available on Netflix (El Nudo). Tele5 has released two open-access comedies, which have successively been incorporated into the Amazon Prime Video catalog, and six series on VOD (four on the latter platform, one on $\mathrm{HBO}$, and one on Netflix). La1 is the only one of the three large state networks that continues to premiere all its fiction in open-access over-the-air, and also offers its fiction on its own free online platform. 
Table 1. Fiction broadcasted in 2020 (national and imported, premieres, reruns and co-productions). State networks

\author{
PREMIERE STATE TITLES - 13 \\ La1 - 9 \\ 1. Cuéntame Cómo Pasó (series) \\ 2. HIT (series) \\ 3. Diarios de la Cuarentena (series) \\ 4. El Ministerio del Tiempo (series) \\ 5. Néboa (series) \\ 6. Servir y Proteger (serial) \\ 7. Historias de Alcafrán (series) \\ 8. Mercado Central (serial) \\ 9. Acacias 38 (serial) \\ Antena3 - 2 \\ 10. El Secreto del Puente Viejo (serial) \\ 11. Amar Es para Siempre (serial)
}

Tele5 - 2

12. Lejos de Ti (series)

13. El Pueblo (series)

\title{
RERUN TITLES - 13
}

La1 - 5

1. Olmos y Robles (series)

2. El Final del Camino (series)

3. Fugitiva (series)

4. El Caso. Crónica de Sucesos (series)

5. Hospital Valle Norte (series)

Tele5 - 3

6. La que Se Avecina (series)

7. Escenas de Matrimonio (sketches)

8. Lo que Escondían Tus Ojos (miniseries)

Cuatro - 1

9. Gym Toni (series)

Divinity - 4

10. Hospital Central (series)

11. MIR (series)

12. Al Salir de Clase (series)

13. Yo Soy Bea (serial)

TOTAL PREMIERE TITLES: 13

Source: Obitel España. 
The wide range of VOD platforms also had an impact on the decrease in reruns, a constant since the consolidation of DTT in 2011. The strategies of the two large private channels, however, are divergent. Thus, while Antena3 is reluctant to broadcast the premieres of Atresplayer openly, Tele5 added Madres, Patria, Perdida and Veneno to its own programming, after their debut on Amazon Prime Video.

The 18 titles of the autonomic networks represent only one less than last year, a figure consistent with the stability in terms of the audience of this group of channels, which have also successfully recovered from the first year of the pandemic. The contribution of the Catalan channel TV3 and the Galician TVG stand out for another year compared to the whole, with five titles each. Aragón TV makes its debut in fiction production with a drama, while ETB1 contributes three miniseries and the end of the fourth and fifth seasons of its successful youth series Go!azen, on air since 2009.

Table 1a. Fiction broadcasted in 2020 (national and imported; premieres, reruns and co-productions). Autonomic networks

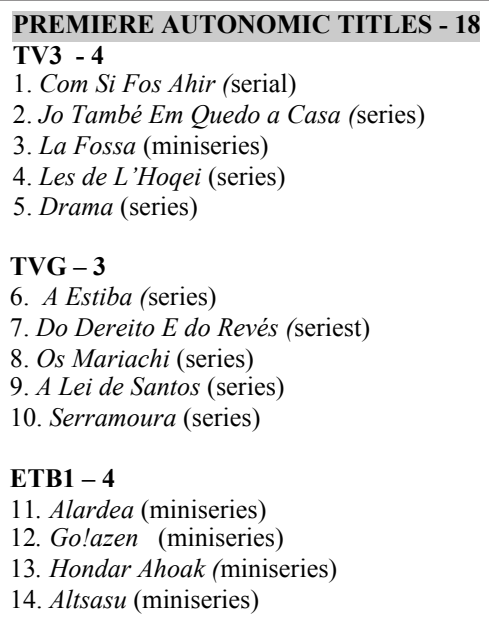


IB3 - 2

15. Mai Neva A Ciutat (series)

16. Pep (series)

\section{Aragón TV}

17. El Último Show (series)

\section{CO-PRODUCTIONS - 1}

\section{TVG - 1}

18. Auga Seca (series) (España y Portugal)

\section{RERUNS -16}

Aragón TV

1. Matalobos (series)

2. La Sala (series)

3. Merlín (series)

\section{À Punt}

4. Açò Es Un Destarifo (series)

5. Unió Musical Da Capo (series)

6. Maniàtics (series)

7. Socarrats (series)

8. Les de L'Hoqei (series)

9. Nit i Dia (series)

10. La Sala (series)

\section{CMT}

11. El Faro (serial)

12. La Sala (series)

13. La Esclava Blanca (series)

\section{RTVC}

14. El Último Show (series)

\section{Telemadrid}

15. La Sala (series)

TOTAL PREMIERE TITLES: 17

TOTAL OBITEL CO-PRODUCTIONS: 1

Source: Obitel España.

The decrease in the number of national fiction premieres on open access over-the-air networks is partially offset by the increase in the number of Ibero-American titles (eight compared to three in 2019). The length of Latin American telenovelas reduces, in turn, the 
difference in hours compared to the previous year (1,380 hours and 35 minutes in 2020 and 1,424 hours in 2019), while determining the slight increase in the number of chapters/episodes (1,564 in 2020 and 1,424 in 2019).

Table 2. State premiere fiction in 2020: Spain

\begin{tabular}{|c|c|c|c|c|c|c|}
\hline Country & Titles & $\%$ & Chap./Ep. & $\%$ & Hours & $\%$ \\
\hline NATIONAL (total) & 13 & 61.9 & 1145 & 73.2 & 1030:10:00 & 74.6 \\
\hline $\begin{array}{l}\text { OBITEL COUNTRIES } \\
\text { (total) }\end{array}$ & 8 & 38.1 & 419 & 26.8 & 350:25:00 & 25.4 \\
\hline Argentina & 0 & 0.0 & 0 & 0.0 & 0:00:00 & 0.0 \\
\hline Brazil & 1 & 4.8 & 31 & 2.0 & $23: 15: 00$ & 1.7 \\
\hline Chile & 0 & 0.0 & 0 & 0.0 & 0:00:00 & 0.0 \\
\hline Colombia & 1 & 4.8 & 42 & 2.7 & $31: 30: 00$ & 2.3 \\
\hline Ecuador & 0 & 0.0 & 0 & 0.0 & 0:00:00 & 0.0 \\
\hline Spain & 13 & 61.9 & 1145 & 73.2 & 1030:10:00 & 74.6 \\
\hline USA (Hispanic productions) & 1 & 4.8 & 105 & 6.7 & $78: 45: 00$ & 5.7 \\
\hline Mexico & 4 & 19.0 & 230 & 14.7 & $205: 55: 00$ & 14.9 \\
\hline Peru & 0 & 0.0 & 0 & 0.0 & 0:00:00 & 0.0 \\
\hline Portugal & 0 & 0.0 & 0 & 0.0 & 0:00:00 & 0.0 \\
\hline Uruguay & 0 & 0.0 & 0 & 0.0 & 0:00:00 & 0.0 \\
\hline Venezuela & 0 & 0.0 & 0 & 0.0 & 0:00:00 & 0.0 \\
\hline CO-PRODUCTIONS (total) & 1 & 100.0 & 11 & 100.0 & 11:00:00 & 100.0 \\
\hline Spanish co-productions & 0 & 0.0 & 0 & 0.0 & 0:00:00 & 0.0 \\
\hline Obitel co-productions & 1 & 100.0 & 11 & 100.0 & 11:00:00 & 100.0 \\
\hline TOTAL GENERAL & 21 & 100.0 & 1564 & 100.0 & 1380:35:00 & 100.0 \\
\hline
\end{tabular}

Source: Obitel España. 
The difference between the number of hours of the Spanish total (national and regional) compared to 2019 is even smaller (1,567 hours and 35 minutes in 2020 compared to 1,681 hours and 10 minutes in 2019), despite the fact that this year there were seven less releases than in the past (39 and 46 respectively). On the other hand, the number of chapters/episodes decreases (1,817 in 2020 and 1,940 in 2019).

Table 2a. State and autonomic premiere fiction in 2020: Spain

\begin{tabular}{|c|c|c|c|c|c|c|}
\hline Country & Titles & $\%$ & Chap./Ep. & $\%$ & Hours & $\%$ \\
\hline NATIONAL (total) & 31 & 79.5 & 1398 & 76.9 & 1217:10:00 & 77.6 \\
\hline OBITEL COUNTRIES (total) & 8 & 20.5 & 419 & 23.1 & $350: 25: 00$ & 22.4 \\
\hline Argentina & 0 & 0.0 & 0 & 0.0 & 0:00:00 & 0.0 \\
\hline Brazil & 1 & 2.6 & 31 & 1.7 & $23: 15: 00$ & 1.5 \\
\hline Chile & 0 & 0.0 & 0 & 0.0 & 0:00:00 & 0.0 \\
\hline Colombia & 1 & 2.6 & 42 & 2.3 & $31: 30: 00$ & 2.0 \\
\hline Ecuador & 0 & 0.0 & 0 & 0.0 & 0:00:00 & 0.0 \\
\hline Spain & 30 & 76.9 & 1392 & 76.6 & 1212:10:00 & 77.3 \\
\hline USA (Hispanic productions) & 1 & 2.6 & 105 & 5.8 & $78: 45: 00$ & 5.0 \\
\hline Mexico & 4 & 10.3 & 230 & 12.7 & 205:55:00 & 13.1 \\
\hline Peru & 0 & 0.0 & 0 & 0.0 & 0:00:00 & 0.0 \\
\hline Portugal & 0 & 0.0 & 0 & 0.0 & 0:00:00 & 0.0 \\
\hline Uruguay & 0 & 0.0 & 0 & 0.0 & 0:00:00 & 0.0 \\
\hline Venezuela & 0 & 0.0 & 0 & 0.0 & 0:00:00 & 0.0 \\
\hline CO-PRODUCTIONS (total) & 2 & 100.0 & 18 & 100.0 & 16:00:00 & 100.0 \\
\hline Spanish co-productions & 1 & 50.0 & 6 & 33.3 & 5:00:00 & 31.3 \\
\hline Obitel co-productions & 1 & 50.0 & 11 & 61.1 & 11:00:00 & 68.8 \\
\hline GRAND TOTAL & 39 & 100.0 & 1817 & 100.0 & $1567: 35: 00$ & 100.0 \\
\hline
\end{tabular}


The five Spanish serials aired on national networks represent $38.5 \%$ of the total formats and 969 hours of broadcast, to which can be added the 350 hours and 25 minutes of the eight premiere telenovelas (100\% of the Latin American total). The significance of this data increases if one takes into account that 2020 is the year in which the telenovelas have returned to national prime time, after almost 30 years of absence, although this time it has done so hand in hand with the Turkish productions Mujer and Mi hija. Thanks to the airings of the latter, released in December, the serial became the first fictional program to be among the most viewed of the year (in ninth position in the annual ranking). ${ }^{9}$

Table 3. Formats of state and Ibero-American fiction

\begin{tabular}{|l|r|r|r|r|r|r|r|r|r|r|r|r|}
\hline \multirow{2}{*}{ Format } & \multicolumn{9}{|c|}{ National } & \multicolumn{6}{|c|}{ Ibero-American } \\
\cline { 2 - 13 } & Titles & $\%$ & $\mathbf{C} / \mathbf{E}$ & $\%$ & $\mathbf{H}$ & $\%$ & Titles & $\%$ & $\mathbf{C} / \mathbf{E}$ & $\%$ & $\mathbf{H}$ & $\%$ \\
\hline $\begin{array}{l}\text { Serial/Telen } \\
\text { ovela }\end{array}$ & 5 & 38.5 & 66 & 5.8 & $969: 00: 00$ & 94.1 & 8 & 100.0 & 419 & 100.0 & $350: 25: 00$ & 100.0 \\
\hline Series & 8 & 61.5 & 1079 & 94.2 & $61: 10: 00$ & 5.9 & 0 & 0.0 & 0 & 0.0 & 0 & 0.0 \\
\hline Miniseries & 0 & 0.0 & 0 & 0.0 & $0: 00: 00$ & 0.0 & 0 & 0.0 & 0 & 0.0 & 0 & 0.0 \\
\hline TV movie & 0 & 0.0 & 0 & 0.0 & $0: 00: 00$ & 0.0 & 0 & 0.0 & 0 & 0.0 & 0 & 0.0 \\
\hline Unitario & 0 & 0.0 & 0 & 0.0 & $0: 00: 00$ & 0.0 & 0 & 0.0 & 0 & 0.0 & 0 & 0.0 \\
\hline Docudrama & 0 & 0.0 & 0 & 0.0 & $0: 00: 00$ & 0.0 & 0 & 0.0 & 0 & 0.0 & 0 & 0.0 \\
\hline Others & 0 & 0.0 & 0 & 0.0 & $0: 00: 00$ & 0.0 & 0 & 0.0 & 0 & 0.0 & 0 & 0.0 \\
\hline
\end{tabular}

Source: Obitel España.

The diversification of formats in 2020 premieres is greater in the Spanish total with respect to national fiction, since the autonomic

9 https://www.infoadex.es/home/wp-content/uploads/2021/02/NP-Estudio-InfoAdex-dela-Inversión-Publicitaria-en-España-2021.pdf 
channels contribute four miniseries (three of which are from ETB1 and one from TV3), although their presence on the air only represents $1 \%$ of the total. On the other hand, the broadcasting time dedicated to homegrown series increased exponentially, with 169 hours of broadcasting (13.9\% compared to $5.9 \%$ for state fiction).

Table 3a. Formats of national, regional and Ibero-American fiction

\begin{tabular}{|c|c|c|c|c|c|c|c|c|c|c|c|c|}
\hline \multirow[b]{2}{*}{ Format } & \multicolumn{6}{|c|}{ National and Regional } & \multicolumn{6}{|c|}{ Ibero-American } \\
\hline & Titles & $\%$ & $\mathbf{C} / \mathbf{E}$ & $\%$ & $\mathbf{H}$ & $\%$ & Title & $\%$ & $\mathbf{C} / \mathbf{E}$ & $\%$ & $\mathbf{H}$ & $\%$ \\
\hline $\begin{array}{l}\text { Serial/Telen } \\
\text { ovela }\end{array}$ & 7 & 22.6 & 178 & 12.7 & $1035: 50: 00$ & 85.1 & 8 & 100.0 & 419 & 100,0 & $350: 25: 00$ & 100.0 \\
\hline Series & 20 & 64.5 & 1204 & 86.1 & 169:00:00 & 13.9 & 0 & 0.0 & 0 & 0.0 & 0 & 0.0 \\
\hline Miniseries & 4 & 12.9 & 16 & 1.1 & $12: 20: 00$ & 1.0 & 0 & 0.0 & 0 & 0.0 & 0 & 0.0 \\
\hline TV movie & 0 & 0.0 & 0 & 0.0 & 0:00:00 & 0.0 & 0 & 0.0 & 0 & 0.0 & 0 & 0.0 \\
\hline Unitario & 0 & 0.0 & 0 & 0.0 & 0:00:00 & 0.0 & 0 & 0.0 & 0 & 0.0 & 0 & 0.0 \\
\hline Docudrama & 0 & 0.0 & 0 & 0.0 & 0:00:00 & 0.0 & 0 & 0.0 & 0 & 0.0 & 0 & 0.0 \\
\hline Others & 0 & 0.0 & 0 & 0.0 & 0:00:00 & 0.0 & 0 & 0.0 & 0 & 0.0 & 0 & 0.0 \\
\hline Total & 31 & 100,0 & 1398 & 100.0 & 1217:10:00 & 100.0 & 8 & 100.0 & 419 & 100.0 & $350: 25: 00$ & 100.0 \\
\hline
\end{tabular}

Source: Obitel España.

The premiere of most of the Antena3 and Tele5 fictions as VOD also highlights La1's contribution to the top 10 of 2020, with six titles. At the same time, it serves as evidence of Tele5's successful strategy to premiere its comedies in open-access. El Pueblo $(2,199,000$ viewers and $16.8 \%$ share) and Lejos de Ti (1,716,000 viewers and $11.8 \%$ share), ranked first and third in the annual ranking respectively. El Pueblo, a creation by the same production company as the popular La que Se Avecina (Contubernio), narrates the complex coexistence between the locals and a group of urbanites recently settled in the prov- 
ince of Soria. Lejos de Ti is a comedy with touches of fantasy and sitcom co-produced by Mediaset España and Cross Production, about the crush of a young Sevillian woman and a Roman who meet at an airport. La1's long-running series Cuéntame Cómo Pasó (2,189,000 viewers and 14.4\% share), set between 1990 and 1991, stands the test of time and places its twentieth season in second position in the annual ranking, with 4.4 share points less than in 2019, which is also worth the 24th position among the most watched programs of the year. ${ }^{10}$

The small number of releases in open-access places three serials in the annual ranking for the first time. The only two premiere fictions offered by Antena3, Amar Es para Siempre (1,253,000 viewers and $10.6 \%$ share) and the final stretch of El Secreto del Puente Viejo $(1,065,000$ viewers and 1.4\%), which said goodbye in May after nine years on air, occupy the sixth and ninth position respectively. Servir $y$ proteger a daily cop-show closes the ranking of the annual top ten.

The importance of female characters in Néboa, the return of teen series to the national prime time (HIT), the stereotypes about contrasts of El Pueblo, and the reflection on the present from the past of the serials, are outstanding aspects of the premieres in open-access state fiction.

Table 4. The ten most watched state titles

\begin{tabular}{|c|c|c|c|c|c|c|c|c|c|}
\hline & Title & Channel & $\begin{array}{c}\begin{array}{c}\text { Country } \\
\text { of } \\
\text { original } \\
\text { idea or } \\
\text { script }\end{array}\end{array}$ & $\begin{array}{c}\text { Format/ } \\
\text { Genre }\end{array}$ & $\mathbf{C} / \mathbf{E}$ & Time Slot & Viewers & Rating & Share \\
\hline 1 & El Pueblo & Tele5 & Spain & $\begin{array}{l}\text { Series / } \\
\text { Comedy }\end{array}$ & 8 & Prime time & $2,199,215$ & 2.5 & 16.3 \\
\hline 2 & $\begin{array}{l}\text { Cuéntame } \\
\text { Cómo } \\
\text { Pasó }\end{array}$ & Lal & Spain & $\begin{array}{l}\text { Series / } \\
\text { Dramedy }\end{array}$ & 12 & Prime time & $2,189,167$ & 4.6 & 14.4 \\
\hline
\end{tabular}

10 http://www.geca.es/geca/informes/20201230--El\%20balance $\% 20 \mathrm{del} \% 20$ a $\%$ C3\%B10\%20-\%202020.pdf 


\begin{tabular}{|c|c|c|c|c|c|c|c|c|c|}
\hline & Title & Channel & $\begin{array}{c}\text { Country } \\
\text { of } \\
\text { original } \\
\text { idea or } \\
\text { script }\end{array}$ & $\begin{array}{c}\text { Format/ } \\
\text { Genre }\end{array}$ & $\mathbf{C} / \mathbf{E}$ & Time Slot & Viewers & Rating & Share \\
\hline 3 & $\begin{array}{l}\text { Lejos de } \\
\text { Ti }\end{array}$ & Tele5 & $\begin{array}{l}\text { Spain- } \\
\text { Italy }\end{array}$ & $\begin{array}{l}\text { Series/ } \\
\text { Comedy }\end{array}$ & 7 & Prime time & $1,716,143$ & 3.6 & 11.8 \\
\hline 5 & $H I T$ & Lal & Spain & $\begin{array}{l}\text { Series / } \\
\text { Drama }\end{array}$ & 10 & Prime time & $1,489,800$ & 3.1 & 9.1 \\
\hline 5 & $\begin{array}{l}\text { Diarios } \\
\text { de la } \\
\text { Cuarente } \\
\text { na }\end{array}$ & La1 & Spain & $\begin{array}{l}\text { Series / } \\
\text { Comedy }\end{array}$ & 8 & Prime time & $1,315,000$ & 2.8 & 6.9 \\
\hline 6 & \begin{tabular}{|l} 
El \\
Ministeri \\
o del \\
Tiempo
\end{tabular} & La1 & Spain & $\begin{array}{l}\text { Series / } \\
\text { Drama }\end{array}$ & 8 & Prime time & $1,298,250$ & 2.7 & 8.0 \\
\hline 7 & \begin{tabular}{|l} 
Amar Es \\
para \\
Siempre
\end{tabular} & Antena3 & Spain & $\begin{array}{l}\text { Serial / } \\
\text { Drama }\end{array}$ & 251 & Afternoon & $1,253,239$ & 2.6 & 10.6 \\
\hline 8 & Néboa & La1 & Spain & $\begin{array}{l}\text { Series / } \\
\text { Thriller }\end{array}$ & 8 & Prime time & $1,234,750$ & 2.6 & 8.4 \\
\hline 9 & $\begin{array}{l}\text { El } \\
\text { Secreto } \\
\text { de Puente } \\
\text { Viejo }\end{array}$ & Antena3 & Spain & $\begin{array}{l}\text { Serial/ } \\
\text { Drama }\end{array}$ & 86 & Afternoon & $1,065,423$ & 2.3 & 9.4 \\
\hline 10 & \begin{tabular}{|l} 
Serviry \\
Proteger
\end{tabular} & La1 & Spain & $\begin{array}{l}\text { Serial / } \\
\text { Copshow }\end{array}$ & 253 & Afternoon & 995,569 & 2.1 & 8.9 \\
\hline
\end{tabular}

Source: Obitel Spain.

For regional TV, the premieres of TV3 and TVG fill, once again, a ranking in which the first contribution of Aragón TV to regional fiction can be found: El Último Show. It is a drama starring the famous Aragonese comedian "Marianico el Corto" (Miguel Ángel Tirado), who mixes his life and his character in a nostalgic remembrance of the past under the direction of Álex Rodrigo, co-director and co-writer of great hits such as Vis a vis (Antena3 and Fox, 2015-2019), La Casa de Papel (Antena3 and Netflix, 2017-) and El Embarcadero (Movistar+, 2019-20), among others.

The second season of Les de L'Hoquei (357,000 viewers and $13.5 \%$ share) tops the annual ranking, after increasing its audience 
dramatically compared to the first installment in a year of general declines. Drama shows that the interest of national networks and VOD platforms in teen series also extends to regional fiction.

Table 4a. The ten most watched autonomic titles

\begin{tabular}{|c|c|c|c|c|c|c|c|c|c|}
\hline & Title & Channel & $\begin{array}{c}\text { Country } \\
\text { of } \\
\text { original } \\
\text { idea or } \\
\text { script }\end{array}$ & Format/Genre & $\mathbf{C} / \mathbf{E}$ & Time Slot & Viewers & Rating & Share \\
\hline 1 & $\begin{array}{l}\text { Les de } \\
\text { l'Hoquei }\end{array}$ & TV3 & Spain & Serial / Drama & 13 & Prime time & 357,000 & 4.9 & 13.5 \\
\hline 2 & $\begin{array}{l}\text { Jo També Em } \\
\text { Quedo a Casa }\end{array}$ & TV3 & Spain & $\begin{array}{l}\text { Series / } \\
\text { Dramedy }\end{array}$ & 20 & Tarde & 293,000 & 4.0 & 13.9 \\
\hline 3 & Drama & TV3 & Spain & Series / Comedia & 6 & Prime time & 280,000 & 3.8 & 11.5 \\
\hline 4 & $\begin{array}{l}\text { Com Si Fos } \\
\text { Ahir }\end{array}$ & TV3 & Spain & Serial / Drama & 112 & Tarde & 258,000 & 0.7 & 16.30 \\
\hline 5 & La Fossa & TV3 & Spain & $\begin{array}{l}\text { Miniseries / } \\
\text { Thriller }\end{array}$ & 4 & Prime time & 205,000 & 2.8 & 9.20 \\
\hline 6 & $\begin{array}{l}\text { A Ley de } \\
\text { Santos }\end{array}$ & TVG & Spain & Series / Thriller & 7 & Prime time & 89,000 & 3.4 & 10.1 \\
\hline 7 & Serramoura & TVG & Spain & Series / Thriller & 18 & Prime time & 87,000 & 3.3 & 10.0 \\
\hline 8 & $\begin{array}{l}\text { O Sabor das } \\
\text { Margaridas }\end{array}$ & TVG & Spain & Series / Thriller & 6 & Prime time & 74,000 & 2.8 & 8.3 \\
\hline 9 & $\begin{array}{l}\text { El Último } \\
\text { Show }\end{array}$ & $\begin{array}{l}\text { AragónT } \\
\text { V }\end{array}$ & Spain & Series / Drama & 8 & Prime time & 71,000 & 5.6 & 12.9 \\
\hline 10 & Auga Seca & $\begin{array}{l}\text { TVG- } \\
\text { RTP }\end{array}$ & $\begin{array}{l}\text { Spain- } \\
\text { Portugal }\end{array}$ & Series / Thriller & 6 & Prime time & 70,000 & 2.7 & 8.1 \\
\hline
\end{tabular}

Source: Obitel Spain.

The top 10 of 2020 includes four TVG thrillers, a genre so popular in Galicia that it has led critics to speak of the "Galician noir boom" to bring together a set of productions characterized by the complexity of the characters, the atmosphere of mystery and the predominant role played by the locations in the stories, which also include Néboa (La1) and El Desorden que Dejas (Netflix). The title that heads 
the classification of the Galician channel (A lei de Santos) is a spin-off of the successful Serramoura, which ended after seven years on air.

\section{2020 VOD Monitoring}

The Stay-at-Home order produced a significant increase in the consumption of VOD platforms. They have continued to grow and expand their content, with an increasingly specialized offer, which shows the maturity of Spanish television fiction production. The 2020 releases include some great international hits (Elite, Las Chicas del Cable) and confirm the relevance of the thriller. $79.1 \%$ of domestic VOD fiction has premiered this year for the first time.

\subsection{VOD platform market}

The supply of digital platforms has continued to increase throughout 2020, as well as their demand (Chart 3). Disney+ has undoubtedly been the most anticipated launch of the year, with an offer of more than 400 films and about 7,500 television episodes at the price of 6.99 euros per month or 69.99 euros per year. In the middle of the confinement, Quibi, the short content platform only for mobile phones, also arrived at Spain. However, only six months later, it confirmed its closure. During the summer, Sky Spain also announced it was shutting down, putting an end to an adventure that began in 2017. Finally, in October, Pluto TV, from ViacomCBS, the first AVOD (advertising-based video on demand) in the Spanish market, landed. This new streaming service, free and without registration, has more than 40 exclusive specialty channels and combines linear and on-demand television.

The platforms already consolidated in our country have also taken advantage of 2020 to improve their positioning in the face of the competition. Orange TV joined forces with AMC Networks International to increase its content offering and launch AMC Selekt, a new 
on-demand service at no additional cost. Netflix began offering, for free, some of its titles; while Amazon Prime Video launched Prime Video Channels, a new service that allows you to add streaming channels without a commitment to stay. Available subscriptions include Starzplay, MGM, and Noggin, among others, with prices ranging from $€ 2.99$ to $€ 9.99$ per month.

Regarding the demand for this type of services, different consulting firms have started to analyze the phenomenon in the absence of official data provided by the companies themselves. According to the study "OTT and payment platforms in Spain", by Barlovento Comunicación ${ }^{11}$, Netflix is the OTT with the highest penetration $(33 \%$ of households), followed by Amazon Prime Video (14.3\%) and HBO Spain $(9.4 \%)$. The results of the sixth wave of the OTT Barometer of the Audiovisual Communication Studies Cabinet (GECA) ${ }^{12}$ corroborate this ranking: Netflix continues to be the platform with the most users in Spain (67.3\% of those surveyed), followed by Amazon Prime Video (62.1\%) and HBO Spain (27.3\%). On the contrary, the Digital TV Research ${ }^{13}$ study points out that Amazon Prime Video and Disney+, with 1.25 million subscribers each, share the second position, only below Netflix (4.2 million subscribers), but ahead of HBO $(731,000)$. However, the only official data is the one from OTTs owned by national channels: Atresplayer Premium ${ }^{14}$ with 452,000 subscribers, and Mitele Plus with 109,000, as of December 31, 2020. ${ }^{15}$

11 http://www.geca.es/geca/informes/20201230--El\%20balance\%20del\%20 a\%C3\%B10\%20-\%202020.pdf

12 https://www.barloventocomunicacion.es/informes-barlovento/analisis-ott-tv-pagoespana/

13 https://www.audiovisual451.com/amazon-y-hbo-las-plataformas-que-mascrecimiento-registran-en-espana-segun-geca/

$14 \mathrm{https} / /$ www.expansion.com/economia-digital/companias/2020/10/30/5f96c $807 \mathrm{e} 5 \mathrm{fdea}$ 28548b4594.html

15 https://www.atresmediacorporacion.com/documents/2021/02/25/ACCF96A3-20884208-8394-DD4B4DCEB6D7/atresmediaresultados_2020cnmv.pdf 


\subsection{Analysis of VOD IN 2020: Premiered Spanish and Ibero- American fictions}

The spectacular growth of VOD in the year of COVID translates into 90 titles released in VOD (68 in 2019), 40 Spanish, 47 Latin American, and three co-productions. Inés del Alma Mía is a SpanishChilean series based on the homonymous novel by Isabel Allende about the life of the first Spanish woman to arrive in Chile, Inés Suárez. Dime Quién Soy is another literary adaptation, in this case of Julia Navarro's bestseller of the same name, produced by DLO Producciones for Movistar+ and Telemundo. The third co-production, the SpanishAmerican thriller The Head, was produced by Mediapro for Hulu Japan and HBO Asia and premiered on Orange TV.

Table 5. National and Ibero-American fictions exhibited in 2020 on VOD systems

\begin{tabular}{|c|c|c|}
\hline $\begin{array}{l}\text { NATIONAL RELEASED } \\
\text { PRODUCTIONS }\end{array}$ & $\begin{array}{c}\text { IBERO-AMERICAN } \\
\text { RELEASED PRODUCTIONS }\end{array}$ & CO-PRODUCTIONS \\
\hline $\begin{array}{l}\text { Netflix - } \mathbf{8} \\
\text { 1. Alguien Tiene que Morir } \\
\text { (miniseries) } \\
\text { 2. El Desorden que Dejas } \\
\text { (series) } \\
\text { 3. Elite (series) } \\
\text { 4. Las Chicas del Cable } \\
\text { (series) } \\
\text { 5. Los Favoritos de Midas } \\
\text { (series) } \\
\text { 6. El Sabor de las Margaritas } \\
\text { (series) } \\
\text { 7. Valeria (series) } \\
\text { 8. Vivir sin Permiso (series) } \\
\text { Movistar+- } \mathbf{1 0} \\
\text { 9. Antidisturbios (series) } \\
\text { 10. El Embarcadero (series) }\end{array}$ & $\begin{array}{l}\text { Netflix - } 37 \\
\text { 1. Bolívar } \\
\text { (telenovela - Mexico) } \\
\text { 2. Casi Feliz } \\
\text { (series - Argentina) } \\
\text { 3. Coisa Mais Linda } \\
\text { (series -Brazil) } \\
\text { 4. Desenfrenadas } \\
\text { (series - Mexico) } \\
\text { 5. Diablero (series - Mexico) } \\
\text { 6. El Dragón } \\
\text { (telenovela - Mexico) } \\
\text { 7. Enemigo Íntimo } \\
\text { (telenovela - USA) } \\
\text { 8. Falsa Identidad } \\
\text { (telenovela - USA) } \\
\text { 9. La Casa de las Flores (series - } \\
\text { Mexico) }\end{array}$ & $\begin{array}{l}\text { Amazon Prime Video - } 1 \\
\text { 1. Inés del Alma Mía } \\
\text { (series - Spain and Chile) } \\
\text { Movistar+ - } \mathbf{2} \\
\text { 2. Dime Quién Soy } \\
\text { (series - Spain and USA) } \\
\text { Orange TV - } \mathbf{1} \\
\text { 3. The Head } \\
\text { (series - Spain and USA) }\end{array}$ \\
\hline
\end{tabular}




\begin{tabular}{|c|c|c|}
\hline $\begin{array}{l}\text { NATIONAL RELEASED } \\
\text { PRODUCTIONS }\end{array}$ & $\begin{array}{c}\text { IBERO-AMERICAN } \\
\text { RELEASED PRODUCTIONS }\end{array}$ & CO-PRODUCTIONS \\
\hline 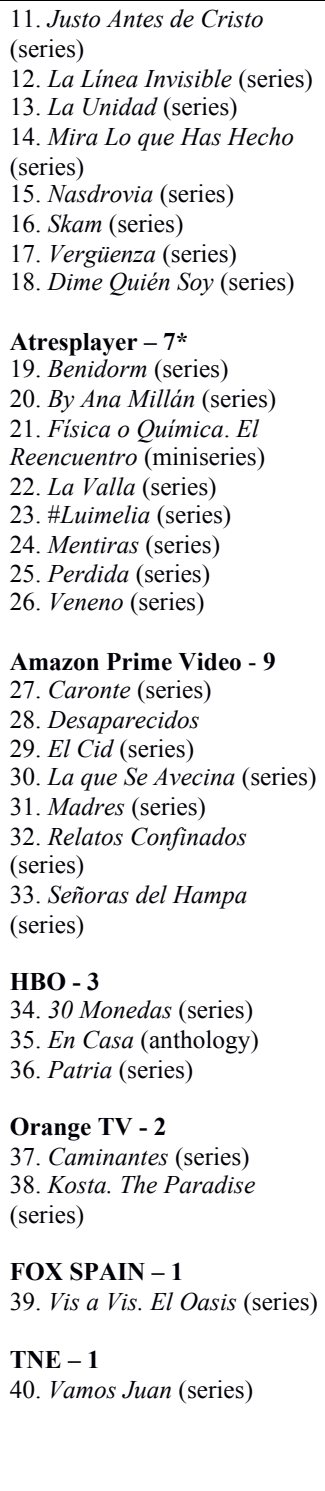 & $\begin{array}{l}\text { 10. La Reina del Flow } \\
\text { (telenovela - Colombia) } \\
\text { 11. Monarca } \text { (series - Mexico) } \\
\text { 12. Narcos Mexico } \\
\text { (series - Mexico) } \\
\text { 13. Omnisciente } \\
\text { (miniseries - Brazil) } \\
\text { 14. Oscuro Deseo } \\
\text { (series - Mexico) } \\
\text { 15. 3\% (series - Brazil) } \\
\text { 16. 100 Dias para Enamorarnos } \\
\text { (telenovela - USA) } \\
\text { 17. Amar and Vivir (telenovela - } \\
\text { Colombia) } \\
\text { 18. Boca a Boca } \\
\text { (series - Brazil) } \\
\text { 19. Buenos Dias Verónica (series } \\
\text { - Brazil) } \\
\text { 20. Control Z (series - Mexico) } \\
\text { 21. El Reto del Beso } \\
\text { (series - Brazil) } \\
\text { 22. El Robo del Siglo } \\
\text { (series - Colombia) } \\
\text { 23. Espectors (series -Brazil) } \\
\text { 24. Historia de Un Crimen } \\
\text { (series - Mexico) } \\
\text { 25. Homemade } \\
\text { (series - Chile - Italy) } \\
\text { 26. Kissing Game } \\
\text { (series - Brazil) } \\
\text { 27. La Venganza de Analia } \\
\text { (telenovela - Colombia) } \\
\text { 28. No Te Puedes Esconder } \\
\text { (series - USA) } \\
\text { 29. Puerta } 7 \\
\text { (series - Argentina) } \\
\text { 30. Reality Z (series - Brazil) } \\
\text { 31. Secreto Bien Guardado } \\
\text { (series - Argentina) } \\
\text { 32. Selena (series) } \\
\text { 33. Siempre Bruja } \\
\text { (series - Colombia) } \\
\text { 34. The Great Heist } \\
\text { (series - Colombia) } \\
\text { 35. The Queen And the } \\
\text { Conqueror } \\
\text { (telenovela - Colombia) } \\
\text { 36. The Unremarcable Juanquini } \\
\text { (series - Colombia) } \\
\text { 37. Chichipatos } \\
\text { (series - Colombia) }\end{array}$ & \\
\hline
\end{tabular}




\begin{tabular}{|c|c|c|}
\hline $\begin{array}{l}\text { NATIONAL RELEASED } \\
\text { PRODUCTIONS }\end{array}$ & $\begin{array}{c}\text { IBERO-AMERICAN } \\
\text { RELEASED PRODUCTIONS }\end{array}$ & CO-PRODUCTIONS \\
\hline & $\begin{array}{l}\text { AMAZON PRIME VIDEO - } 7 \\
\text { 38. Cómo Sobrevivir Soltero } \\
\text { (series - Mexico) } \\
\text { 39. De Brutas Nada } \\
\text { (series - Brazil) } \\
\text { 40. El Candidato } \\
\text { (series - Mexico) } \\
\text { 41. El Presidente } \\
\text { (series - Chile - Argentina) } \\
\text { 42. La Jauria (series - Chile) } \\
\text { 43. Pan and Circo } \\
\text { (series - Mexico) } \\
\text { FOX - 3 } \\
\text { 44. El General Naranjo (series - } \\
\text { Colombia) } \\
\text { 45. Llámame Bruna (series - } \\
\text { Brazil) } \\
\text { 46. Aqui en la Tierra (series - } \\
\text { Mexico) } \\
\text { HBO - 1 } \\
\text { 47. Dignidad (series - Chile) }\end{array}$ & \\
\hline Total: 40 & Total: 47 & Total: 3 \\
\hline
\end{tabular}

Source: Obitel Spain

Mexico regains the primacy of Ibero-American contributions with 13 titles (10 in 2019), closely followed by Colombia (11 titles) and Brazil (10 titles). Argentina premieres two less titles than in 2019. 
Table 6. VOD premiered fiction in 2020: countries of origin

\begin{tabular}{|l|r|r|}
\hline \multicolumn{1}{|c|}{ Country } & \multicolumn{1}{c|}{ Titles } & \multicolumn{1}{c|}{$\%$} \\
\hline Argentina & 3 & 3.3 \\
\hline Brazil & 10 & 11.1 \\
\hline Chile & 3 & 3.3 \\
\hline Colombia & 11 & 12.2 \\
\hline Ecuador & 0 & 0.0 \\
\hline Spain & 40 & 44.4 \\
\hline USA (Hispanic productions) & 5 & 5.6 \\
\hline Mexico & 13 & 14.4 \\
\hline Peru & 0 & 0.0 \\
\hline Portugal & 0 & 0.0 \\
\hline Uruguay & $\mathbf{9 0}$ & $\mathbf{1 0 0 . 0}$ \\
\hline Venezuela & $\mathbf{2}$ & 0.0 \\
\hline CO-PRODUCTIONS (total) & 0 & 0.0 \\
\hline Spanish co-productions & $\mathbf{5}$ & $\mathbf{5 . 6}$ \\
\hline Obitel co-productions & $\mathbf{3}$ & 3.3 \\
\hline TOTAL GENERAL & & 2.2 \\
\hline
\end{tabular}

Source: Obitel Spain

The series is the dominant format, with a sequencing in episodes - generally with chapter structure - that ranges between 6 and 18 and an average duration of approximately 30 minutes for comedies, and between 45 and 60 minutes for the rest of the productions. 
Table 7. VOD Formats of national and Ibero-American fiction

\begin{tabular}{|c|c|c|c|c|c|c|c|c|}
\hline \multirow{2}{*}{ Format } & \multicolumn{4}{|c|}{ National } & \multicolumn{4}{|c|}{ Ibero-american } \\
\hline & Titles & $\%$ & $\begin{array}{l}\mathbf{C} / \\
\mathbf{E}\end{array}$ & $\%$ & Titles & $\%$ & $\mathbf{C} / \mathbf{E}$ & $\%$ \\
\hline Serial/Telenovela & 0 & 0.0 & 0 & 0.0 & 9 & 19.1 & 573 & 63.4 \\
\hline Series & 40 & 93.0 & 315 & 97.2 & 38 & 80.9 & 331 & 36.6 \\
\hline Miniseries & 2 & 4.7 & 4 & 1.2 & 0 & 0.0 & 0 & 0.0 \\
\hline TV movie & 0 & 0.0 & 0 & 0.0 & 0 & 0.0 & 0 & 0.0 \\
\hline Unitario & 0 & 0.0 & 0 & 0.0 & 0 & 0.0 & 0 & 0.0 \\
\hline Anthology & 1 & 2.3 & 5 & 1.5 & 0 & 0.0 & 0 & 0.0 \\
\hline Others (soap opera, etc.) & 0 & 0.0 & 0 & 0.0 & 0 & 0.0 & 0 & 0.0 \\
\hline Total & 43 & 100.0 & 324 & 100.0 & 47 & 100.0 & 904 & 100.0 \\
\hline
\end{tabular}

Source: Obitel Spain

\section{Fiction and audience participation in digital environments}

Open-access fictions and VOD platforms have concentrated their transmedia expansion mainly on social networks and new sound formats. Among their strategies stands out the microsite "lavalla2045. com", for La Valla which, in addition to the classic sections (characters, best moments, etc.), includes exclusive content: a clandestine radio station; a compilation of mobile videos about the series' dystopian world and a ration card, whose coupons offer access to complementary material. Like \#Luimelia, this series also takes advantage of social networks to make viral content by creating stickers.

Premiere fictions continue to inspire special debate programs (Más de Veneno: El Documental or Patria: Detrás de la Serie) or about the topics it addresses (Hit and ¿Quién educa a quién?). Patria and La 
Linea Invisible, two fictions focused on ETA, also have documentary podcasts, while other universes well known to the audience (La que Se Avecina, Vis a vis, and Acacias 38) expand as podcasts.

Reference productions in their transmedia expansion have not stopped innovating either. Two weeks before the premiere of its fourth season, El Ministerio del Tiempo launched the 10-minute prequel "Antes de que no haya tiempo", which bridges the gap between the last two seasons. Skam Spain held a "live" party to promote the episode "El concierto" and, although the clips of said episode were already recorded, the party was reproduced in detail to make live updates on social networks and invite a score of fans. The initiative made the hashtag \#SkamSpain the first trend on Twitter Spain, and it was among the main trends in Chile, Mexico and Peru. ${ }^{16}$

\section{1. \#Luimelia, transmedia and social audience}

The couple formed by Luisita and Amelia, from the serial Amar Es para Siempre, enjoy great popularity on social networks and have ended up becoming a viral phenomenon. The volume of tweets increased by more than $1,000 \%$ between the sixth (2017-2018) and the seventh season (2018-2019), as the audience increased the shippeo (a term that fans use to refer to the relationship between the two female characters), catapulting the series from position 36 (T6) to position 2 (T7) on the Social TV ranking ${ }^{17}$. The enthusiasm aroused by the serial led Atresmedia to turn this love story into an independent universe. This is how \#Luimelia was born. With a hashtag as a nod to the fans and the digital environment in which the production was born, the Atresplayer Premium fiction moves Luisita and Amelia from 1977 (the

16 https://files.mediaset.es/file/10002/2021/02/24/FY_20_SPANISH_CNMV_f7a7.pdf

17 Noticia de https://diagonaltv.es/noticia/arranca-la-segunda-y-tercera-temporada-deluimelia/ 
year of the original setting of their relationship in Amar Es para Siempre) to 2020 .

With the goal to have fans enjoy and connect as much as possible with the fiction, \#Luimelia completes the experience by combining the broadcast of the episodes with the social networks of both female characters. On their Twitter and Instagram profiles, the popular couple posts unpublished content from their daily lives, gives their opinion on current affairs, interacts with each other, with other characters in the series and with their followers, who feel them as close as real people. At the end of 2020, the accounts of the lead characters already totaled more than 16,000 .

The two seasons released during 2020 were social audience hits. In December, \#Luimelia exceeded 718,000 tweets and accumulated more than 180 million real impressions and 42 national trending topics. In addition, all the episodes of the first season were in the top 10 of the ranking of the most talked about of all televisions and platforms, while those of the second season increased their visibility and are among the first three positions. ${ }^{18}$

\section{Highlights of the year}

The didactic character of Lal's fictions is evident in all its formats, with bets as innovative and risky as some VOD premieres. The teen series HIT $(1,490,000$ viewers and 9.1\%) portrays the extreme behaviors of a group of school-aged children in their relationship with issues as relevant to young people as sex, addictions, social networks, etc. Néboa $(1,235,000$ viewers and 8.4\%), one of the

$18 \mathrm{https} / / /$ premium.atresplayer.com/luimelia/noticias/estreno-tercera-temporada-proximomes-enero_202012115fd3828559ccfa000179d602.html 
most notable Spanish series of 2020, is a fast-paced thriller set in the misty landscapes of a small Galician island where a series of murders take place, apparently related to other crimes of the past. The return of the fourth season of El Ministerio del Tiempo (1,298,000 viewers and $8.0 \%$ ), after the exclusive airing of the third installment on Netflix, has once again fulfilled the expectations of its followers with episodes as memorable as, for example, the crossover between the poet Federico García Lorca, murdered at the beginning of the Spanish Civil War, and the flamenco singer Camarón de la Isla, who died in 1992.

The regional televisions, whose 18 titles this year exceed the open-access premieres of national televisions, have experienced a less marked decline in the audience than the latter. The second season of Les de L'Hoquei (357,000 viewers and 13.5\% share) tops a ranking led once again by TV3 fictions, among which the youth dramedy Drama stands out (280,000 viewers and $11.5 \%$ of share), a bilingual series also aired by Playz and YouTube, which has sparked a heated controversy on social networks about the combined use of Catalan and Spanish. La fossa (205,000 viewers and 9.2 share), another of the novelties of the Catalan channel, is a thriller with a slow pace and a cinematic look that, like Néboa, has a policewoman in the lead. Same as the TVG thriller El Sabor de Las Margaritas (74,000 viewers and 8.3\%), whose first season became the most watched foreign-language fiction on Netflix in the UK and Ireland last April. ${ }^{19}$

The 44 VOD fiction premieres in 2020 offer a wide range of genres and themes that reflect the diversity, versatility and high average quality of Spanish fiction production. Once again, Movistar+ is the platform with the highest number of titles (10) in an extremely competitive year. The police show Antidisturbios has been the most-

19 https:/www.farodevigo.es/sociedad/2019/05/11/sabor-margaritas-triunfa-reinounido-15697207.html 
watched series on the Telefónica platform and one of the best valued, with a sustained audience of over $80 \%$ (nine out of ten people who have started to watch it have finished it $)^{20}$. It is followed by La Linea Invisible, about the foundation of ETA and the first murders committed by the armed gang, and La Unidad, a sophisticated policeman with impeccable workmanship, set in the fight against jihadist terrorism. The retrospective look at ETA is also the objective of Patria, an adaptation of the homonymous novel by Fernando Aramburu that shares the spotlight on HBO with 30 Monedas, the horror thriller with paranormal elements by filmmaker Álex de la Iglesia.

Atresplayer includes among its most popular fictions two claims of gender diversity: the aforementioned \#Luimelia and Veneno, the biopic of a transsexual devoured by the exhibitionist television of the late night shows of the nineties. The latter, re-broadcast by Antena3 in October, obtained an average of 2,424,000 viewers (16.9\% share), 2.5 points above the most viewed fiction of the year, Cuéntame Cómo Pasó, which places it in the 18 position of ranking of the most watched programs. On the contrary, the retransmission on Tele 5 of his comedy La que Se Avecina, after the premiere of its twelfth season on Amazon Prime Video, has not suffered the same fate $(1,536,000$ viewers and $9.2 \%$ share).

In addition to the five Tele5 fictions aired on Amazon Prime Video, the Mediaset group also has two other premiere series this year on HBO and Netflix respectively: the aforementioned Patria and the second season of Vivir sin Permiso, which on this occasion has prioritized drama over thriller.

The third season of Élite constitutes Netflix's commitment to teen series, with this youth drama becoming one of the most viewed fictions worldwide on the North American platform. Netflix also in-

20 https://comunicacion.movistarplus.es/email/antidisturbios-ya-es-la-serie-masvista-en-movistar-este-2020 
cludes among its eight 2020 premieres the fifth and final season of Las Chicas del Cable and the adaptation of Carlos Montero's thriller El Desorden que Dejas, of which he is also a director and screenwriter. Finally, it is worth highlighting the debut of Spanish OrangeTV with three thrillers: Caminantes, the aforementioned The Head and the co-production with Finland Kosta. The Paradise.

\section{Topic of the year: the fiction industry in times of pandemic}

The first year of the pandemic paralyzed the audiovisual industry. All television shootings were postponed, including those of national fiction, which by mid-March amounted to about thirty ${ }^{21}$. Other tasks in the production chain were also affected, although thanks to technology they were adapted to virtual scriptwriting, as well as the pre and post-production processes.

The highlight of the year came from the television industry itself, which tried to turn imposed need into creative opportunity. Thus, it set out to reflect on confinement from the realization of fictions in exceptional conditions, those allowed inside homes. A response that aspired to remedy the lack - and the delay - of premieres in full social isolation due to the coronavirus, as well as providing a constructive audiovisual representation of that unprecedented experience that we were discovering. Confinement and Covid-19 instantly emerged as inspirational themes for creating television fiction. Public channels and VOD platforms produced and aired fictions whose content dealt with and showed the reality of the crisis.

The first initiatives came from the public networks. TV3 premiered on April 1 Jo També Em Quedo a Casa, a daily tragicomedy

21 https://vertele.eldiario.es/noticias/Todas-series-suspendidas-canceladas-coronavirusespana-estados-unidos-usa_0_2213478646.html 
of 20 episodes, produced by Yumagic, written by Blanca Bardagil and Sergi Cervera, and directed by the latter. It raises the issue of the emotional separation of a couple that is forced to live together due to confinement. It is a brief proposal, 15 minutes per chapter and technically austere, which uses standard fixed shots in the interactions between characters inserted through supposed video calls and social networks. The filming took place in a few days, with two technicians who traveled to the actors' houses and recorded with an elementary set: microphone, camera and a couple of spotlights.

A week later, TVE premiered Diarios de Cuarentena during prime time, an initiative of Morena Films, written and directed by Álvaro Fernández-Armero and David Marqués. It was presented in a sitcom format, with eight episodes of 30 minutes each in continuity, based on intertwined plots that narrated different daily experiences lived in confined homes. The local customs and manners story sought to reflect current affairs through humor, entertaining the audience and empathizing with it through comic situations of seclusion. It was set in a dozen houses and interpreted by actors, couples and partners, who were also in charge of the filming, decoration, costumes and makeup. Despite the modest audience (8.4\% share), TVE announced the sale of the format for adaptation in France and Mexico. ${ }^{22}$

The VOD platforms chose to commission work from different filmmakers to form anthological series, whose common theme was the pandemic or confinement. HBO Spain turned to young filmmakers Leticia Dolera, Rodrigo Sorogoyen, Paula Ortiz, Carlos Marques-Marcet, Elena Martín - to compose En casa, a miniseries made up of five medium-length films of 15 to 40 minutes each, which address, through different genres, the particular view of the filmmakers from and about

$22 \mathrm{https} / / /$ vertele.eldiario.es/noticias/Diarios-de-la-Cuarentena-Espana-Tendraadaptaciones-Francia-Mexico_0_2222477770.html 
the confinement. In general terms, one glimpses an authorial collection, where personal relationships make up the common denominator that intertwines the disparity of the stories. Despite the limitations of the confinement, the production of the series was carried out in record time, since not even two months elapsed between the announcement of the project (April 14) and its premiere (June 3).

A month later, Amazon Prime Video joined with a similar compilation: Relatos Con-fin-a-dos, a creation by Álvaro Longoria and Cecilia Gessa also shot during the confinement by a dozen actors in their homes. Its five self-concluding episodes, of 20 minutes each, were directed by Fernando Colomo, Miguel Bardem, Juan Diego Botto and the creators of Diarios de Cuarentena: Álvaro Sánchez-Armero and David Marqués. In this case, the narratives share the theme of isolation from singular approaches, with unexpected plot twists.

The original series of the platforms presented personal, asymmetrical and artistic stories. The narrated stories extended the representation of confinement, expanded the plurality of collective memory and complemented, through more experimental proposals, the stories offered by public channels, more often based in everyday situations. It was about fulfilling a mission of an emotional nature, which evidenced identification with the audience through humor, empathy and some examples of collectivity, contact and collaboration between people.

With these proposals, the industry has proven initiative, creative avidity, dynamism and ability to adapt to the circumstances. There is also a certain aesthetic precariousness -homogenization of resources, plans, sets- and narrative simplification due to the lack of time, resources and technical professionals. In any case, the different contributions make up a testimonial fiction of the pandemic that has functioned as a multifaceted and diverse chronicle, executed during the first wave of infections when the maximum restrictions on mobility 
prevailed, with the difficulties that this entailed: creating and planning quickly, overcoming technical difficulties and expressiveness with a slower narrative rhythm.

At the juncture of the confinement, the working model adopted a similar form. Each household of actors received a telephone, a microphone and a tripod to record their scenes. The artistic cast added to the interpretive tasks other techniques - from camera operator to makeup artist - with limited resources. Then they sent the recorded material to the editors and directors - who had previously rehearsed and provided technical instructions to the cast by video call - while the scriptwriters wrote against the clock.

Beyond the titles cited, the rest of the fictions resisted incorporating the pandemic into their narrative universes. Adding the virus in the new plots entailed the risk of normalizing it and involved changing the tone and aesthetics of the projects, in addition to losing the expression of the interpreters under their face masks. In fact, the only production where the coronavirus was inoculated was Cuéntame Cómo Pasó. The scriptwriters proposed for season 21 (which will begin on January 14, 2021) a time jump from 1992 to 2020 , to show the incidence of the pandemic, which places the Alcántara's youngest daughter fighting the virus in the front line as a doctor while the writer son takes care of his parents. The temporary alteration and its connection with the present is justified by valuing the pandemic as an event so extraordinary that it manages to occupy a privileged place in the album of the country's historical moments represented as a mirror in the series.

Regarding the distribution of fiction in streaming on free channels, it is worth mentioning the Spanish-Australian co-production Cancelled (Screen Australia), which tells the story of its protagonists 
-the actress María Albiñana and the film director Luke Eve- who had to cancel their wedding at the last minute due to the coronavirus and confine themselves with his mother, in Valencia. A naturalistic story, halfway between comedy and drama, articulated in 10 chapters, each 9 minutes long, which premiered on Facebook, went to the VIX platform -where it achieved two million views in 48 countries- and won several international awards, such as the best series of 2020 at the British Web Awards. $^{23}$

Given the global paralysis and the uncertainty generated by the evolution of the epidemic, the reactivation of television fiction production was not reached until the end of May, in phase 1 of the deescalation. The productions then resumed filming, in a staggered manner, although conditioned by the protocols required by the Ministry of Health and prepared by, among others, the Aggrupation of Audiovisual Associations $(A A A)$ or the Association of Television Fiction Directors (Dirige), in order to avoid occupational risks and new infections. Among the measures, the following stood out: limitation of 25 people in the capacity of the set, carrying out PCR tests, taking the temperature, expansion of spaces to maintain the safety distance, online casting or equipment for disinfection of areas, material and clothing. It is estimated that the measures increased the cost of production between 2 and $10 \% .^{24}$

The wave of the pandemic also reached the scripts. For example, in the serials with intense recording rhythms (Mercado Central, Amar Es para Siempre and Acacias 38) the scripts were rewritten to adapt them to new filming needs, reduce the number of extras, delay

23 https://www.eldiario.es/sociedad/serie-confinamiento-cancelled-gana-5-premiosbritish-web-awards_1_6475378.html

$24 \mathrm{https} / /$ www.elmundo.es/cultura/cine/2020/06/24/5ef2003ffc6c83f8018b45ef.html 
certain plots or avoid sequences with physical contact ${ }^{25}$. Some of the new scenes were solved with ellipsis or recorded in layers five feet apart and then staged in parallel to give the impression that the performers were together when in fact they were captured separately.

Television fiction emerged as an essential and recurring entertainment resource for audiences during the pandemic. It was able to reinvent itself and assumed functions of representation, containment and relief at this critical moment in recent history.

25 https://elpais.com/television/2020-05-02/como-devolver-la-normalidad-a-la-televisiontras-la-crisis-del-coronavirus.html 